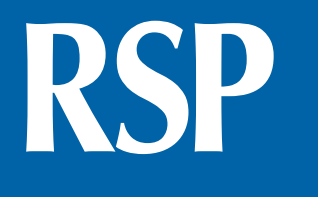

http://www.rsp.fsp.usp.br/
Revista de

Saúde Pública

\title{
Oral health in the agenda of priorities in public health
}

José Leopoldo Ferreira Antunes', Tatiana Natasha Toporcov', João Luiz Bastos", Paulo Frazão"', Paulo Capel Narvai'", Marco Aurélio Peres ${ }^{\mathrm{IV}}$

I Departamento de Epidemiologia. Faculdade de Saúde Pública. Universidade de São Paulo. São Paulo, SP, Brasil

" Programa de Pós-Graduação em Saúde Coletiva. Centro de Ciências da Saúde. Universidade Federal de Santa Catarina. Florianópolis, SC, Brasil

III Departamento de Prática de Saúde Pública. Faculdade de Saúde Pública. Universidade de São Paulo. São Paulo, SP, Brasil

Iv Australian Research Centre for Population Oral Health. School of Dentistry. The University of Adelaide. Adelaide, Australia

\section{ABSTRACT}

This study describes the scientific production on oral health diffused in Revista de Saúde Pública, in the 50 years of its publication. A narrative review study was carried out using PubMed, as it is the search database that indexes all issues of the journal. From 1967 to 2015, 162 manuscripts specifically focused on oral health themes were published. This theme was present in all volumes of the journal, with increasing participation over the years. Dental caries was the most studied theme, constantly present in the journal since its first issue. Periodontal disease, fluorosis, malocclusions, and other themes emerged even before the decline of dental caries indicators. Oral health policy is the most recurring theme in the last two decades. Revista de Saúde Pública has been an important vehicle for dissemination, communication, and reflection on oral health, contributing in a relevant way to the technical-scientific interaction between professionals in this field.

DESCRIPTORS: Dental Caries. Oral Health. Public Health. Review. Historical Article.

\section{Correspondence:}

José Leopoldo Ferreira Antunes

Faculdade de Saúde Pública

Av. Dr. Arnaldo, 715 Cerqueira César

01246-904 São Paulo, SP, Brasil

E-mail: leopoldo@usp.br

Received: 22 Apr 2016

Approved: 10 Jul 2016

How to cite: Antunes JLF, Toporcov TN, Bastos JL, Frazão P, Narvai PC, Peres MA. Oral health in the agenda of priorities in public health. Rev Saude Publica.

2016;50:57.

Copyright: This is an open-access article distributed under the terms of the Creative Commons Attribution License, which permits unrestricted use, distribution, and reproduction in any medium, provided that the original author and source are credited. 


\section{INTRODUCTION}

Many oral health conditions are recognized as public health problems because of their prevalence, severity, individual and community impact, which entail costs to the health system and the existence of effective methods of prevention and treatment ${ }^{10,59}$. Untreated dental caries is considered the most prevalent condition throughout the world ${ }^{22}$; severe periodontal disease is the sixth ${ }^{21}$.

Recognizing the importance of oral and craniofacial diseases on the global burden of morbidity and in association with systemic diseases, treatment costs and the possibility of applying effective measures of promotion and prevention, the 60th World Assembly of the World Health Organization adopted a resolution recommending the member states to increase budgetary appropriations devoted to the control of such diseases and conditions ${ }^{66}$. In Brazil, oral health is one of the three most important reasons for health care demand ${ }^{20}$.

As public health problems, confronting adverse conditions of oral health requires coordinated action on the part of the society, in particular of health services. To guide this action, it is essential to conduct epidemiological studies, of planning and management, and studies on social sciences in health specifically focusing on such conditions in its multiple dimensions.

This understanding permeates the entire history of Revista de Saúde Pública (RSP). When celebrating its 40 years, we noted that oral health was one of the main thematic areas of the journal ${ }^{38}$. By studies published in this scientific dissemination vehicle, we can ponder the participation of oral health issues in the evolution of the agenda of priorities in public health.

On the occasion of RSP's 50th anniversary, the present study aimed at describing the scientific production on oral health issues diffused in the journal throughout its history.

\section{Published Articles}

We carried out a narrative review study. For the retrieval of the published articles, we used the PubMed search database, which indexes all issues of the journal. Two examiners conducted the search independently and resolved conflicts by consensus. The selected articles were classified in subthemes and synthesis for presentation purposes.

From 1967 to 2015, RSP published 162 manuscripts specifically focused on oral health themes, including original articles, theoretical review, reviews, editorials, and previous notes. The Figure shows the distribution of these articles by decades (blocks) and three-year periods (line), showing that RSP approached these themes since its early years and that the concentration of the journal regarding oral health has grown over time.

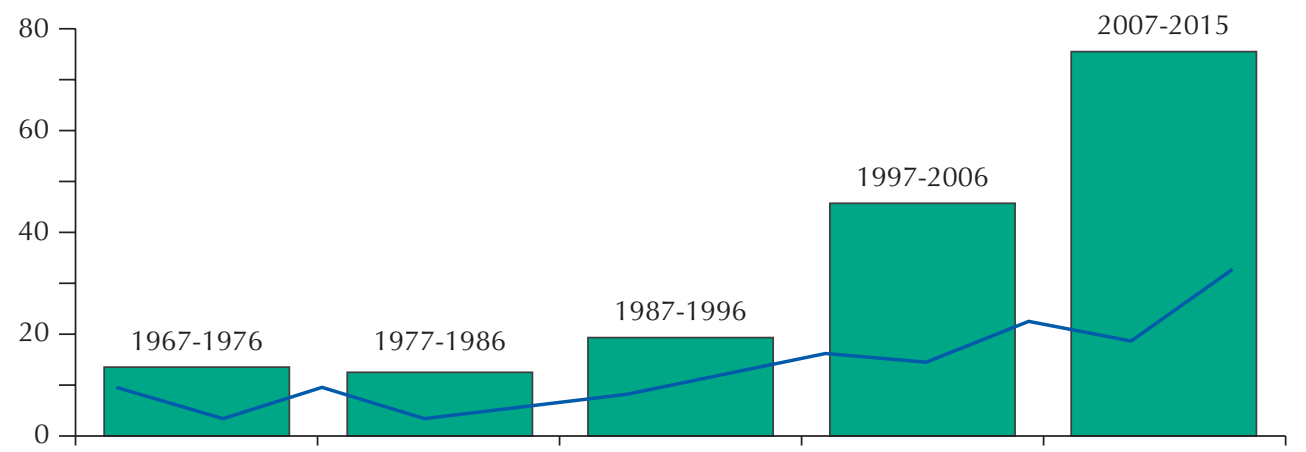

Figure. Number of articles on oral health themes published in Revista de Saúde Pública, according to decades (blocks) and three-year periods (line). Sao Paulo, SP, Southeastern Brazil, 1967-2015. 


\section{Dental Caries: Prevalence Studies and Inequality}

Dental caries was the oral health condition that most motivated studies on the pages of RSP. It was also a constant theme during the five decades of the journal. Sixty-nine articles assessed the prevalence of dental caries in the population in general and in specific groups, inequality in its distribution, preventive resources, and methodological aspects of the forms of measuring the severity.

Already in its early years, dental caries prevalence was described for different cities, having as reference the addition of fluoride in the water supply system ${ }^{62,63}$. These studies have contributed to consolidate the conviction that water fluoridation is effective in reducing dental caries indicators, and should, therefore, be extended.

Anticipating the concern with social inequalities in health, pioneering studies addressed differences in the prevalence of dental caries according to social strata. In the first issue of RSP, Souza et al..$^{56}$ compared indicators of the disease among black and white school children; this inequality would be studied again in the journals of $1970^{57}$ and $19744^{7}$. Viegas ${ }^{65}$ assessed the incidence of dental caries during pregnancy; Castellanos ${ }^{7}$ studied the prevalence of the disease in orphanages in the city of Sao Paulo. The first study to evaluate socioeconomic differentials in the experience of the disease was published by Yankilevich et al. ${ }^{67}$, having as reference the city of Córdoba, in Argentina, and employing a Marxist-inspired approach, using the concept of social classes.

In the latest period, a decline in the prevalence of dental caries was observed. Articles published in RSP described and analyzed empirical data justifying this observation. Narvai et al. ${ }^{34}$ compared the results of epidemiological surveys of dental caries carried out in the city of Sao Paulo from 1970 to 1996, and concluded that the reduction of dental caries indicators was largely due to the addition of fluoride in public water supply and in dentifrices, as well as the introduction of preventive programs in the public health network. In the same period, Freysleben et al. ${ }^{17}$ compared the presence of dental caries in school children of Florianopolis in 1971 and 1997, concluding that the reduction of the prevalence was real and could not be attributed only to changes in diagnostic criteria.

However, the decline in dental caries prevalence was accompanied by increased inequality of their indicators between the social strata. This phenomenon, referred to as polarization of dental caries experience ${ }^{35}$, was also described and analyzed in the pages of RSP for different age groups ${ }^{3,16,55}$.

\section{Original Themes and Methodological Innovations}

Methodological aspects of measures of dental caries in the population also motivated pioneering studies on RSP. In 1973, Souza ${ }^{58}$ evaluated a synthetic measure of dental caries experience by simplifying the traditional Decay-missing-filled (DMF) index, which accounts for the decayed teeth, lost due to dental caries and filled (restored). This theme would be explored in the pages of the journal by Guimarães and Guimarães ${ }^{19}$, who proposed original and simplified methodology for measuring prevalence of dental caries and which was applied in subsequent studies ${ }^{12}$.

Analytical techniques widely used in studies on public health also had pioneer application to the area of oral health in the pages of RSP. Linear regression ${ }^{61}$ and logistic regression ${ }^{40}$ were applied to test the association between dental caries experience and behavioral and socioeconomic factors. RSP also innovated by publishing, in 1997, a study with georeferencing of dental caries indicators in the municipalities of the state of Sao Paulo ${ }^{44}$. In 2007, Celeste et al. ${ }^{9}$ published the first article on RSP employing multilevel analysis to relate dental caries indicators in adolescents with the characteristics of individuals and their residential contexts.

Still considering original themes of research in oral health, RSP has published studies that, in time, have had an impact on the prevention of dental caries. Mouthwashes and topical 
applications of fluoride gel in mouth trays were object of study already in the first volumes of the journal, becoming popular in Brazi ${ }^{8,46,64}$. Pinto ${ }^{47}$ considered the hypothesis of the addition of fluoride to common salt and underlined the conditions under which the measure could be considered a complement to water fluoridation in the Brazilian context. Peres et al. ${ }^{42}$ described the addition of sugar in syrups and oral drug solutions, with potential damage to children's oral health. The participation of pediatricians ${ }^{51}$ and community health agents ${ }^{15}$ in promoting children's oral health also promoted original research on RSP.

The aging of the population, a theme so important to contemporary public health, motivated studies on oral health in RSP in different periods. Dental caries, periodontal disease, dental loss, and prosthetic use were discussed, in 1992, in a study identifying the need for specific odontological policies and programs for older people ${ }^{50}$. Still focused on this age group, several studies have addressed the data of epidemiological surveys carried out in Brazil in recent decades. Singh et al. ${ }^{54}$ analyzed obesity and dental loss in older people and showed that these conditions relate differently between the sexes. Martins et al. ${ }^{30}$ studied the relationship between oral health conditions and housing, individual characteristics, and behavior in a study that included more than 5,000 older people of Brazil.

Figueiredo et al. ${ }^{14}$ evaluated the masticatory capacity of adults in Florianopolis, and Ribeiro et al. ${ }^{49}$ described the dental loss of adults and focused the preservation of functional teeth and reduced dental arch as alternatives to prosthetic treatment. Still regarding the latest period, articles on other original themes were published, which are still reverberating in professional field and have given rise to new approaches such as self-perception of oral health of teenagers ${ }^{41}$ and adults ${ }^{27}$, and the manifestation of lesions of the oral mucosa in patients with HIV/AIDS ${ }^{45}$.

The welfare of professionals working with oral health have also motivated studies. Regarding the decrease in risk of infection of these professionals, Martins and Barreto ${ }^{32}$ described prevalence of vaccination for hepatitis B virus among dentists according to area of expertise, while Garcia and Blank ${ }^{18}$ found the adequacy of occupational post-exposure conducts to biological material for oral health workers. Nunes and Freire ${ }^{36}$ evaluated the quality of life of public health dentists and found low values in physical and psychological domains and high in social relations and environment domains.

\section{Emerging Themes}

Even before the decline of dental caries indicators, other oral health themes emerged as public health problems, requiring action of health authorities and health services. In particular, several studies of RSP focused on distribution, forms of measurement, associated factors, and consequences of malocclusion, gingival inflammation, and periodontal diseases, conditions widely prevalent.

Tomita et al. ${ }^{60}$ pointed the relationship between sucking habits and severity of occlusion such as open bite, dental crowding, and cross bite. The theme would return to the pages of the journal in $2007^{39}$ and $2013^{53}$. In 1969, the need for gingival treatment was the subject of $\mathrm{RSP}^{6}$. Periodontal disease, gingival bleeding, and dental calculus were themes of the journal, including evaluating the possible association between their manifestation in pregnant women and the birth of children with low weight ${ }^{11}$.

Dental fluorosis, another emerging theme on the agenda of priorities in public health, was present in the pages of RSP in the last two decades of its 50 years. Studies with different methodological schemes assessed its prevalence and its perception by the population as well as the related beliefs and attitudes. Lima and $\mathrm{Cury}^{24}$ measured fluoride intake of children by water and dentifrice. Subsequent studies have evaluated the concentration of fluoride in several foods and bottled water for sale.

Oral cancer and orofacial clefts are less prevalent conditions; but their severity justifies the inclusion on the agenda of priorities in public health. These themes are also present in 
RSP, in the latest period. Loffredo et al. estimated the incidence of oral clefts in Brazil ${ }^{25}$ and carried out a case-control study ${ }^{26}$ pointing heredity and pollution as the main risk factors. Oral cancer has been studied as to its risk factors ${ }^{28,29}$ and inequalities of gender and race ${ }^{2}$.

The planning of dental services for patients requiring special care has also been the object of studies published in RSP. Oliveira et al. ${ }^{37}$ studied the dental care aimed at children and adolescents with Down syndrome, and underlined the importance of the orientation of health professionals who take care of these patients in order to provide full care. Elizondo et al. ${ }^{13}$ analyzed the dental care aimed at patients with HIV/AIDS in Mexico by examining their perception regarding the persistence of stigma on the part of professionals.

\section{Oral Health Policies}

The study on oral health policies stood out in the last two decades. About a third of the articles published in RSP in this period addressed oral health policies and related issues of the planning and management of dental services. Such studies proposed and evaluated programs such as fluoridation of the water supply network, preventive procedures and of oral health promotion, the importance of the auxiliary professionals composing oral health teams in direct provision of services, and the dental care in public and private networks.

Even before the Brazilian Unified Health System (SUS) was deployed, Vitor Gomes Pinto ${ }^{48}$ published an article on RSP scaling the treatment needs and human resources in the dental area in order to foster the implementation of a program of basic oral health services of national range. In the following years, the dental care in SUS has been evaluated regarding its extent and effectiveness.

Lacerda et al. ${ }^{23}$ and Martins et al. ${ }^{31}$ evaluated factors associated with self-perception of need to visit the dentist such as pain of dental origin and difficult to chew. Baldani et al. ${ }^{4}$ analyzed the provision of public dental services in Paraná and identified an expansion in oral health actions in previous years, with a pro-equity trend in the provision and use of dental services in primary health care. Antunes and $\mathrm{Narvai}^{1}$ also evaluated favorably the expansion of dental care in the public network after the implementation, on the part of SUS, of Family Health Strategy and of Dental Specialties Centers. Peres et al. ${ }^{43}$ documented the reduction in inequalities between socioeconomic strata when using dental services, comparing data collected in 2003 and 2008 for National Research by Residential Samples. Moysés et al. ${ }^{33}$ analyzed the surveillance policy of oral health in force in Brazil, highlighting, on one hand, expressive progress and, on the other, obstacles and difficulties still present.

Camargo et al. ${ }^{5}$ evaluated the use of dental services in pre-scholar children, distinguishing the reason that led to the consultation. By this strategy, they could identify factors associated with consultations aimed at routine evaluation and to solve problems. They concluded that the rate of use of dental services of pre-scholar children is still lesser than that of medical consultations (childcare) and also that, besides the socioeconomic condition, maternal behaviors have an important role for using routine dental services.

On the occasion of the ten-year anniversary of the Programa Brasil Sorridente (Smiling Brazil Program), Scherer and Scherer ${ }^{52}$ have focused the changes at work in oral health in primary health care, identifying progress achieved and challenges still persistent at work in oral health at this level of care. According to the authors, the public network professionals tend to reproduce the dominant biomedical model, requiring continued efforts of management, training, and permanent education for understanding the dynamics of the work in order to get significant changes to local realities.

\section{Final Considerations}

RSP has been an important vehicle of communication of scientific knowledge in the field of collective oral health. Since its first issue, and in all its volumes, the journal has been 
publishing search results about oral health themes of interest to public health, contributing to scientific reflection, professional training, and health planning. The Brazilian Ministry of Health recognized the importance of the journal for the scientific communication in the field of oral health, choosing it to publish, in 2013, a supplement to studies describing and analyzing the results of the National Survey on Oral Health, the epidemiological survey, also known as SBBrasil 2010.

Dental caries has held a prominent position in the published articles. It was also the study on dental caries that, in part, promoted the discussion of methodological innovations, both in terms of its evaluation in epidemiological investigations, and in statistical techniques of analysis. Over time, other harms to oral health, such as adverse periodontal conditions,fluorosis, malocclusions, and oral cancer, were explored according to varied theoretical-methodological perspectives and linked to the Brazilian context.

The growth of publications in the thematic area of policies, planning, management, and evaluation of oral health services sought to answer, among other priorities, the problem represented by dental caries, including demands for qualified services to handle its direct demonstration or more severe consequences. Publications diffused in RSP expose a set of major transformations in scientific thought and valuation of the oral health theme.

The synthetic description of these studies provides identifying the involvement of different oral health themes in the evolution of the agenda of priorities in public health. The journal has been employed by researchers in the field as an instrument of dissemination, communication, and reflection of scientific knowledge, contributing in a relevant way to education and technical, scientific, and professional interaction.

\section{REFERENCES}

1. Antunes JLF, Narvai PC. Políticas de saúde bucal no Brasil e seu impacto sobre as desigualdades em saúde. Rev Saude Publica. 2010;44(2):360-5. DOI:10.1590/S0034-89102010000200018

2. Antunes JLF, Toporcov TN, Biazevic MG, Boing AF, Bastos JL. Gender and racial inequalities in trends of oral cancer mortality in Sao Paulo, Brazil. Rev Saude Publica. 2013;47(3):470-8. DOI:10.1590/S0034-8910.2013047003724

3. Ardenghi TM, Piovesan C, Antunes JLF. Desigualdades na prevalência de cárie dentária não tratada em crianças pré-escolares no Brasil. Rev Saude Publica. 2013;47(Suppl 3):129-37. DOI:10.1590/S0034-8910.2013047004352

4. Baldani MH, Almeida ES, Antunes JLF. Eqüidade e provisão de serviços públicos odontológicos no estado do Paraná. Rev Saude Publica. 2009;43(3):446-54. DOI:10.1590/S0034-89102009000300008

5. Camargo MBJ, Barros AJD, Frazão P, Matijasevich A, Santos IS, Peres MA et al. Preditores da realização de consultas odontológicas de rotina e por problema em pré-escolares. Rev Saude Publica. 2012;46(1):87-97. DOI:10.1590/S0034-89102012005000004

6. Cardoso GM. Verificação da aplicabilidade e comportamento do índice de Lowell Smith, para estimar as necessidades de tratamento gengival. Rev Saude Publica. 1969;3(2):117-32. DOI:10.1590/S0034-89101969000200001

7. Castellanos RA. Aspectos epidemiológicos da cárie dental em escolares brancos e não brancos de ambos os sexos internos em sete orfanatos da cidade de São Paulo, Brasil, em 1972. Rev Saude Publica. 1974;8(1):51-62. DOI:10.1590/S0034-89101974000100006

8. Castellanos RA. Estudo comparativo do efeito de solução de $\mathrm{NaF}$ a 0,5\%, através de bochecho, escovação e ambos, na prevenção da cárie dental. Rev Saude Publica. 1983;17(6):461-75. DOI:10.1590/S0034-89101983000600003

9. Celeste RK, Nadanovsky P, De Leon AP. Associação entre procedimentos preventivos no serviço público de odontologia e a prevalência de cárie dentária. Rev Saude Publica. 2007;41(5):830-8. DOI:10.1590/S0034-89102007000500018

10. Costa JSD, Victora CG. O que é "um problema de saúde pública"? Rev Bras Epidemiol. 2006;9(1):144-6. DOI:10.1590/S1415-790X2006000100018 
11. Cruz SS, Costa MC, Gomes Filho IS, Vianna MI, Santos CT. Doença periodontal materna como fator associado ao baixo peso ao nascer. Rev Saude Publica. 2005;39(5):782-7. DOI:10.1590/ S0034-89102005000500013

12. Cypriano S, Sousa MLR, Wada RS. Avaliação de índices CPOD simplificados em levantamentos epidemiológicos de cárie dentária. Rev Saude Publica. 2005;39(2):285-92. DOI:10.1590/S0034-89102005000200021

13. Elizondo JE, Treviño AC, Violant D. Dentistry and HIV/AIDS related stigma. Rev Saude Publica. 2015;49:79. DOI:10.1590/S0034-8910.2015049005877

14. Figueiredo DR, Peres MA, Luchi CA, Peres KG. Fatores associados às dificuldades de adultos na mastigação. Rev Saude Publica. 2013;47(6):1028-38. DOI:10.1590/S0034-89102013000901028

15. Frazão P, Marques D. Efetividade de programa de agentes comunitários na promoção da saúde bucal. Rev Saude Publica. 2009;43(3):463-71. DOI:10.1590/S0034-89102009000300010

16. Freire MC, Reis SC, Figueiredo N, Peres KG, Moreira RS, Antunes JLF. Determinantes individuais e contextuais da cárie em crianças brasileiras de 12 anos em 2010. Rev Saude Publica. 2013;47(Supl 3):40-9. DOI:10.1590/S0034-8910.2013047004322

17. Freysleben GR, Peres MA, Marcenes W. Prevalência de cárie e CPO-D médio em escolares de doze a treze anos de idade nos anos de 1971 e 1997, região Sul, Brasil. Rev Saude Publica. 2000;34(3):304-8. DOI:10.1590/S0034-89102000000300015

18. Garcia LP, Blank VL. Condutas pós-exposição ocupacional a material biológico na odontologia. Rev Saude Publica. 2008;42(2):279-86. DOI:10.1590/S0034-89102008000200013

19. Guimarães LOC, Guimarães AMR. Simplificação do índice CPO dos 18 aos 25 anos Rev Saude Publica. 1990;24(5):407-11. DOI:10.1590/S0034-89101990000500009

20. Instituto Brasileiro de Geografia e Estatística. Um panorama da saúde no Brasil: acesso e utilização dos serviços, condições de saúde e fatores de risco e proteção à saúde 2008. Rio de Janeiro: Instituto Brasileiro de Geografia e Estatística; 2010 [citado 2016 abr 22]. Disponível em: http://www.ibge.gov.br/home/estatistica/populacao/panorama_saude_brasil_2003_2008/

21. Kassebaum NJ, Bernabé E, Dahiya M, Bhandari B, Murray CJ, Marcenes W. Global burden of severe periodontitis in 1990-2010: a systematic review and meta-regression. J Dent Res. 2014;93(11):1045-53. DOI:10.1177/0022034514552491

22. Kassebaum NJ, Bernabé E, Dahiya M, Bhandari B, Murray CJ, Marcenes W. Global burden of untreated caries: a systematic review and metaregression. J Dent Res. 2015;94(5):650-8. DOI:10.1177/0022034515573272

23. Lacerda JT, Simionato EM, Peres KG, Peres MA, Traebert J, Marcenes W. Dor de origem dental como motivo de consulta odontológica em uma população adulta. Rev Saude Publica. 2004;38(3):453-8. DOI:10.1590/S0034-89102004000300017

24. Lima YB, Cury JA. Ingestão de flúor por crianças pela água e dentifrício. Rev Saude Publica. 2001;35(6):576-81. DOI:10.1590/S0034-89102001000600012

25. Loffredo LCM, Freitas JA, Grigolli AA. Prevalência de fissuras orais de 1975 a 1994. Rev Saude Publica. 2001;35(6):571-5. DOI:10.1590/S0034-89102001000600011

26. Loffredo LCM, Souza JM, Yunes J, Freitas JA, Spiri WC. Fissuras lábio-palatais: estudo casocontrole. Rev Saude Publica. 1994;28(3):213-7. DOI:10.1590/S0034-89101994000300009

27. Luchi CA, Peres KG, Bastos JL, Peres MA. Desigualdades na autoavaliação da saúde bucal em adultos. Rev Saude Publica. 2013;47(4):740-51. DOI:10.1590/S0034-8910.2013047004364

28. Marchioni DM, Fisberg RM, Góis-Filho JF, Kowalski LP, Carvalho MB, Abrahão M et al. Dietary patterns and risk of oral cancer: a case-control study in São Paulo, Brazil. Rev Saude Publica. 2007;41(1):19-26. DOI:10.1590/S0034-89102007000100004

29. Marques LA, Eluf-Neto J, Figueiredo RA, Góis-Filho JF, Kowalski LP, Carvalho MB et al. Oral health, hygiene practices and oral cancer. Rev Saude Publica. 2008;42(3):471-9. DOI:10.1590/ S0034-89102008000300012

30. Martins AM, Barreto SM, Silveira MF, Santa-Rosa TT, Pereira RD. Autopercepção da saúde bucal entre idosos brasileiros. Rev Saude Publica. 2010;44(5):912-22. DOI:10.1590/S0034-89102010005000028

31. Martins AM, Barreto SM, Pordeus IA. Fatores relacionados à autopercepção da necessidade de tratamento odontológico entre idosos. Rev Saude Publica. 2008;42(3):487-96.

DOI:10.1590/S0034-89102008000300014 
32. Martins AM, Barreto SM. Vacinação contra a hepatite B entre cirurgiões dentistas. Rev Saude Publica. 2003;37(3):333-8. DOI:10.1590/S0034-89102003000300011

33. Moysés SJ, Pucca Junior GA, Paludetto Junior M, Moura L. Avanços e desafios à Política de Vigilância à Saúde Bucal no Brasil. Rev Saude Publica. 2013;47(Suppl 3):161-7. DOI:10.1590/S0034-8910.2013047004329

34. Narvai PC, Castellanos RA, Frazão P. Prevalência de cárie em dentes permanentes de escolares do Município de São Paulo, SP, 1970-1996. Rev Saude Publica. 2000;34(2):196-200. DOI:10.1590/S0034-89102000000200015

35. Narvai PC, Frazão P, Roncalli AG, Antunes JLF. Cárie dentária no Brasil: declínio, polarização, iniqüidade e exclusão social. Rev Panam Salud Publica. 2006;19(6):385-93. DOI:10.1590/S1020-49892006000600004

36. Nunes MF, Freire MCM. Qualidade de vida de cirurgiões-dentistas que atuam em um serviço público. Rev Saude Publica. 2006;40(6):1019-26. DOI:10.1590/S0034-89102006000700009

37. Oliveira AC, Czeresnia D, Paiva SM, Campos MR, Ferreira EF. Uso de serviços odontológicos por pacientes com síndrome de Down. Rev Saude Publica. 2008;42(4):693-9. DOI:10.1590/S0034-89102008000400016

38. Pereira JCR. Revista de Saúde Pública: quarenta anos da produção científica no Brasil. Rev Saude Publica. 2006;40(N Esp):148-59. DOI:10.1590/S0034-89102006000400020

39. Peres KG, Barros AJ, Peres MA, Victora CG. Effects of breastfeeding and sucking habits on malocclusion in a birth cohort study. Rev Saude Publica. 2007;41(3):343-50. DOI:10.1590/S0034-89102007000300004

40. Peres KG, Bastos JRM, Latorre MRDO. Severidade de cárie em crianças e relação com aspectos sociais e comportamentais. Rev Saude Publica. 2000;34(4):402-8. DOI:10.1590/S0034-89102000000400014

41. Peres KG, Cascaes AM, Leão ATT, Côrtes MIS, Vettore MV. Aspectos sociodemográficos e clínicos da qualidade de vida relacionada à saúde bucal em adolescentes. Rev Saude Publica. 2013;47(Supl 3):19-28. DOI:10.1590/S0034-8910.2013047004361

42. Peres KG, Oliveira CT, Peres MA, Raymundo MS, Fett R. Sugar content in liquid oral medicines for children. Rev Saude Publica. 2005;39(3):486-9. DOI:10.1590/S0034-89102005000300022

43. Peres KG, Peres MA, Boing AF, Bertoldi AD, Bastos JL, Barros AJ. Redução das desigualdades sociais na utilização de serviços odontológicos no Brasil entre 1998 e 2008. Rev Saude Publica. 2012;46(2):250-8. DOI:10.1590/S0034-89102012000200007

44. Peres MA, Narvai PC, Calvo MC. Prevalência de cárie dentária em crianças aos doze anos de idade, em localidades do Estado de São Paulo, Brasil, período 1990-1995. Rev Saude Publica. 1997;31(6):594-600. DOI:10.1590/S0034-89101997000700008

45. Petruzzi MNMR, Cherubini K, Salum FG, Figueiredo MAZ. Risk factors of HIV-related oral lesions in adults. Rev Saude Publica. 2013;47(1):52-9. DOI:10.1590/S0034-89102013000100008

46. Pinto IL. Prevenção da cárie dental com aplicações tópicas semestrais de flúor-fosfato acidulado. Rev Saude Publica. 1993;27(4):277-90. DOI:10.1590/S0034-89101993000400008

47. Pinto VG. Prevenção da cárie dental: a questão da fluoretação do sal. Rev Saude Publica. 1982;16(1):66-72. DOI:10.1590/S0034-89101982000100006

48. Pinto VG. Saúde bucal no Brasil. Rev Saude Publica. 1983;17(4):316-27. DOI:10.1590/S0034-89101983000400006

49. Ribeiro MT, Rosa MA, Lima RM, Vargas AM, Haddad JP, Ferreira EF. Edentulism and shortened dental arch in Brazilian elderly from the National Survey of Oral Health 2003. Rev Saude Publica. 2011;45(5):817-23. DOI:10.1590/S0034-89102011005000057

50. Rosa AGF, Castellanos Fernandez RA, Pinto VG, Ramos LR. Condições de saúde bucal em pessoas de 60 anos ou mais no Município de São Paulo (Brasil). Rev Saude Publica. 1992;26(3):155-60. DOI:10.1590/S0034-89101992000300005

51. Schalka MMS, Rodrigues CRMD. A importância do médico pediatra na promoção da saúde bucal. Rev Saude Publica. 1996;30(2):179-86. DOI:10.1590/S0034-89101996000200010

52. Scherer $\mathrm{Cl}$, Scherer MD. Avanços e desafios da saúde bucal após uma década de Programa Brasil Sorridente. Rev Saude Publica. 2015;49:98. DOI:10.1590/S0034-8910.2015049005961 
53. Silveira LM, Prade LS, Ruede AM, Haeffner LSB, Weinmann ARM. Aleitamento materno e sua influência nas habilidades orais de crianças. Rev Saude Publica. 2013;47(1):37-43. DOI:10.1590/S0034-89102013000100006

54. Singh A, Peres MA, Peres KG, Bernardo CO, Xavier A, D'Orsi E. Gender differences in the association between tooth loss and obesity among older adults in Brazil. Rev Saude Publica. 2015;49:44. DOI:/10.1590/S0034-8910.2015049005590

55. Sousa MLR, Rando-Meirelles MPM, Tôrres LHN, Frias AC. Cárie dentária e necessidades de tratamento em adolescentes paulistas. Rev Saude Publica. 2013;47(Supl 3):50-8. DOI:10.1590/S0034-8910.2013047004340

56. Souza JMP, Arrillaga AN, Ochoa FV, Rocha O. Prevalência da cárie dental em brancos e não brancos. Rev Saude Publica. 1967;1(1):38-43. DOI:10.1590/S0034-89101967000100006

57. Souza JMP. Atendimento dentário de crianças de oito a doze anos de idade, nos grupos escolares estaduais da capital de São Paulo. Rev Saude Publica. 1970;4(1):61-70. DOI:10.1590/S0034-89101970000100010

58. Souza JMP. CPO e MID: alguns resultados obtidos em meninos brancos, de 8 a 12 anos. Rev Saude Publica. 1973;7(2):93-101. DOI:10.1590/S0034-89101973000200003

59. Thomson WM, Sheiham A, Spencer AJ. Sociobehavioral aspects of periodontal disease. Periodontol. 2000 2012:60(1):54-63. DOI:10.1111/j.1600-0757.2011.00405.x

60. Tomita NE, Bijella VT, Franco LJ. Relação entre hábitos bucais e má oclusão em pré-escolares. Rev Saude Publica. 2000;34(3):299-303. DOI:10.1590/S0034-89102000000300014

61. Tomita NE, Bijella VT, Lopes ES, Franco LJ. Prevalência de cárie dentária em crianças da faixa etária de 0 a 6 anos matriculadas em creches: importância de fatores socioeconômicos. Rev Saude Publica. 1996;30(5):413-20. DOI:10.1590/S0034-8910199600050000310.1590/S0034-89101985000400001

62. Viegas Y, Viegas AR. Análise dos dados de prevalência de cárie dental na cidade de Barretos, SP, Brasil, depois de dez anos de fluoretação da água de abastecimento público. Rev Saude Publica. 1985;19(4):287-99. DOI:10.1590/S0034-89101985000400001

63. Viegas $Y$, Viegas AR. Análise dos dados de prevalência de cárie dental na cidade de Campinas, SP, Brasil, depois de dez anos de fluoração da água de abastecimento público. Rev Saude Publica. 1974;8(4):399-409. DOI:10.1590/S0034-89101974000400006

64. Viegas Y. Efeito inibidor de cárie dental de uma única aplicação tópica de solução de fluofosfato acidulada em adultos jovens. Experiência de um ano. Rev Saude Publica. 1970;4(1):55-60. DOI:10.1590/S0034-89101970000100009

65. Viegas Y. Gestação e cárie dental. Rev Saude Publica. 1970;4(1):71-7. DOI:10.1590/S0034-89101970000100011

66. World Health Organization. World Health Assembly. Oral health: action plan for promotion and integrated disease prevention: report by Secretariat. Geneva: World Health Organization; 2007 [2016 abr 22]. Disponível em: http://apps.who.int/iris/handle/10665/22448

67. Yankilevich ERLM, Cattoni STD, Cornejo LS, Battellino LJ. Distribución de la caries dental en niños preescolares en una región urbana, Argentina, 1992. Rev Saude Publica. 1993;27(6):436-44. DOI:10.1590/S0034-89101993000600006

Authors' Contribution: Conception and planning of the study: JLFA, TNT. All authors participated in the data collection and analysis, the writing of the manuscript, and the approval of the final version. All authors assume public responsibility for the content of the article.

Conflict of Interest: The authors declare no conflict of interest. 